\title{
УДК 930.26 (571.5) \\ https://doi.org/10.24852/2587-6112.2020.6.366.378 \\ ПАЛЬМЫ С ВТУЛЬЧАТЫМ НАКОНЕЧНИКОМ ИЗ БАЙКАЛЬСКОГО РЕГИОНА И ИХ БОЛЕЕ ПОЗДНИЕ МОДИФИКАЦИИ
}

\author{
(c) 2020 г. А.В. Харинский
}

В статье рассматривается вопрос о формировании в степях и лесостепях Евразии различных оружейных комплексов. Новые виды оружия быстро распространялись по всему лесостепному коридору континента, становясь достоянием большей части кочевников и полукочевников. Исключением является появление и распространение древкового оружия с однолезвийным наконечником и несомкнутой втулкой, известного на территории Байкальского региона в конце I - начале II тыс. н.э. Их использовали для нанесения колющего или рубяще-режущего удара. C XVII в. пальма с черешковым насадом получает широкое распространение среди жителей лесной зоны Северной Азии, становясь одним из важнейших видов вооружения у якутов, эвенков, селькупов, хантов, кетов и других сибирских и дальневосточных народов.

Ключевые слова: археология, вооружение, Байкальский регион, древковое клинковое втульчатое оружие, пальма, Северная Азия, традиционное оружие, этнография, монголы, якуты, эвенки.

\section{PALMAS WITH SLEEVE TIPS FROM THE BAIKAL REGION AND THEIR LATER MODIFICATIONS}

\section{A. V. Kharinsky}

The paper addresses the issue of origination of various weapon systems in the steppes and forest-steppes of Eurasia. The new types of weapons rapidly spread across the forest-steppe corridor of the continent, as they were mastered by the majority of the nomads and semi-nomads. An exception was the emergence and spread of polearms with a single-bladed tip and an open socket, which was spread in the Baikal region in late 1st early 2nd Millennia AD. They were used for stabbing or chopping and cutting blows. Since the 17th century, the palmas with pediculate tips were widely spread among the inhabitants of the forest zone of North Asia, becoming one of the most important types of weapons among the Yakuts, Evenks, Selkups, Khanty, Kets and other Siberian and Far Eastern peoples.

Keywords: archaeology, Baikal region, pal'ma, knife, sleeve, shaft, grave, Turkic-speaking tribes, Yakuts, Evenks.

\section{Введение}

На протяжении столетий в степях и лесостепях Евразии происходило формирование различных оружейных комплексов. Их появление сопровождалось изменениями, влиявшими на разные стороны жизни скотоводческих сообществ, в том числе и на геополитическую ситуацию в регионе. Новые виды оружия как правило достаточно быстро распространялись по всему лесостепному коридору континента, становясь достоянием большей части кочевников и полукочевников. Правда и в подобных тенденциях существовали иногда исключения. К их числу относится процесс появления и распространения древкового оружия с однолезвийным наконечником и несомкнутой втулкой, известного на территории Байкальского региона в конце I начале II тыс. н.э.

Назначение этих изделий оценивалось исследователями по-разному. И.В. Асеев характеризовал подобное оружие, обнаруженное на островах в истоке Ангары, как «ножи однолезвийные с втульчатой рукояткой» (Асеев, 1980, с. 99). Подобные изделия из юго-восточного Забайкалья он вместе с И.И. Кирилловым и Е.В. Ковычевым определял, как большой железный нож (Асеев и др., 1984, с. 52). По мнению И.Л. Кызласова, однолезвийные наконечники с втульчатым насадом могли являться «боевыми штыковидными ножами» (Кызласов, 1983, с. 38). Одну из подобных находок с территории Тувы Ю.С. Худяков назвал «наконечником копья кинжаловидной формы» (Худяков, 1980, с. 98).

В работах, опубликованных Ю.С. Худяковым в начале 1990-х годов (1991, с. 18; 1992), интерпретация однолезвийных наконечников с несомкнутой втулкой, представленных в материалах средневековых памятников Предбайкалья и Забайкалья изменилась. По мнению исследователя, длинная втул- 
ка с отверстием для крепления на конце у данных предметов аналогична втулкам копий. Расширение втулок к концу свидетельствует в пользу того, что они крепились на длинных древках, а сама втулка не могла выполнять функции рукояти. Их использовали для нанесения колющего или рубяще-режущего удара. По своим размерам эти предметы близки к наконечникам копий или нередко превышают их. С подобной характеристикой этих изделий нельзя не согласиться (Харинский, 2001, с. 140-141). Несомкнутую втулку такого клинка неудобно держать в руках, а тем более использовать для колки или резания. Даже если ее обмотать тканью, берестой или какимнибудь иным покрытием, то это не улучшит ее качеств. В связи с этим, рассматривать несомкнутую втулку как рукоять ножа не правомерно. Она служила для крепления клинка к древку, за которое держал это оружие его обладатель.

Похожие по форме наконечники были распространены у жителей Сибири в XVII-XX вв. и известны среди русского населения под названием «пальма́». Так как по форме и функциям пальма напоминала нож, то у нее, как и у ножа можно выделить те же конструктивные элементы - клинок и насад, а противолежащие стороны клинка определить как лезвие и обушок. Клинок пальмы имеет прямой обушок, заканчивающийся острием. Лезвие прямое, закругляющееся к острию или скругленное. Длина клинка от 10 до 70 см. В сечении клинок треугольный. Насад, как правило, черешковый, хотя встречаются экземпляры и с втульчатым насадом. У пальм с черешковым насадом место крепления к древку обматывалось сухожилиями или кожей Длина древка обычно составляла от 1 до 1,5, изредка до 2 м.

Черешковые пальмы Восточной Сибири

Поздние формы пальмы́, обычно, имеют черешковый насад. При этом встречается как массивный широкий черешок, как, например, у якутских образцов пальмы, так и узкий, как у наконечников из Предбайкалья. Обушок пальмы прямой и зачастую образует с черешком единую линию. Наличие прямого обушка без дополнительных шипов отличало этот вид оружия от близких ему по функциям западноевропейских глеф, японских нагинат или китайских гуань дао.

У западной группы эвенков пальма́ именовалась «кото», а у восточной «уткэн». Она представляла собой массивный односторон- не острый тесак длинной 50-60 см. Нижним концом он вставлялся в расщепленное древко, которое укреплялось с помощью наклеенной полоски бересты. Длина палки у западных эвенков превышала рост человека, у восточных достигала 1 м. Кроме этого, эвенками использовалось копье «гида» с двухсторонне острым наконечником листовидной формы с втульчатым насадом. Большинство эвенков предпочитало иметь пальму, которая была тяжелее, ее использовали также в качестве топора (Василевич, 1969, с. 64).

Примером эвенкийской пальмы может служить клинок, обнаруженный в захоронении Лударская губа 1, датирующемся вторую половину XVIII в., на северном побережье озера Байкал (Харинский, 2003). Древко пальмы не сохранилось. Судя по расположению клинка, оно находилось около левой руки (или в руке) погребенного. Его длина составляла около 50-60 см. а длина пальмы в целом 70-80 см. Металлическая часть пальмы напоминала черешковый нож (рис. 1-1). Черешок (насад) отделяется от клинка лезвийным и обушковым уступами, ширина которых составляет около 1 см. Обушок прямой. Острие сужается с лезвийной стороны. Кончик острия обломан. Лезвие заточено с левой стороны. Первоначальная длина клинка составляла -20 см, ширина основания клинка - 3,5 см. ширина основания насада 1,3 cм, длина насада - 6 см. В продольном сечении черешок клиновидной формы. Он плавно сужается к вершине. В месте соединения клинка и насада фиксируются остатки древка, оканчивающегося оловянной обоймой овальной формы. Ее ширина - 3,6 см, толщина - 2,7 см. С двух сторон обойма оканчивалась муфтами. Одна из муфт охватывала клинок, а другая древко. Клинковая муфта треугольная в сечении. Ее ширина - 3,6 см, высота - 0.5 см, толщина в обушковой части - 0,9 см. Древковая муфта состоит из сердечника, охватывающего черенок, и внешнего двухслойного обода, опоясывающего конец древка. Два внешние слоя древковой муфты имеют толщину по 0,2 см. Накладываясь друг на друга, они образуют узор, состоящий из расположенных в ряд наклонных четырехугольников.

Широкое распространение пальмы получила среди якутов. Существовало две их разновидности «батас» и «батыйа». В.Л. Серошевский писал о батас: «Лезвие его длиной в три четверти с лишком аршина, с прямой, тупой спинкой, с острым концом, посередине 
слегка расширяющимся, так что острие образует ломаную линию. Ширина его у деревца $1 \frac{1}{4}$ дюйма, а в самом широком месте $1 \frac{1}{2}$ дюйма. Толщина $1 / 8$ дюйма. Его березовая ручка к концу становится толще. У лезвия она не толще 1 дюйма в диаметре. Нередко она обернута скотскими сухожилиями, обклеена черненной кожей и украшена с обеих сторон двумя узкими продольными полосками белой бересты.... Им можно колоть и рубить. Точно такое их охотничье копье, батыя-хотохан, только острие его поменьше и пошире. Лезвие копья нередко гравировано, украшено простой, но изящной резьбой, медными и серебряными насечками. Их особенность заключается в том, что острия их сточены с правой стороны, между тем как у остальных режущих инструментов, включая топор и косу, якуты стачивают левую сторону» (Серошевский, 1993, с. 380-381).

По определению Э.К. Пекарского, батыйа является копьем в виде широкого и толстого ножа, укрепленного в березовом древке. Оно на ремешке висело на руке, служа запасным оружием (пекарский, 1958, с. 409). По мнению А.И. Гоголева батыйа - это разновидность более крупной якутской пальмы батас. Подобное оружие (рис. 1 - 2) было обнаружено во время раскопок поселения Оргумай (Гоголев, 1990, табл. XXVIII-16, 17), датирующегося концом XVI-XVII вв. Широкое распространение такие пальмы получают в XVIII вв. (Гоголев, 1990, с.54). А.И. Гоголев считает, что пальма является изобретением якутов. Первоначально она имела втульчатый насад. «Постепенно, по всей вероятности, в бассейне Средней Лены древние якуты стали пользоваться черешковыми пальмами, ставшими одним из индикаторов якутской этнографической культуры» (Гоголев. 1990, с. 105). На изобретение пальмы батас, якутами указывает и Ф.Ф. Васильев (Васильев, 1995, с. 92).

К числу наиболее ранних черешковых пальм на территории Якутии относятся находки в захоронениях Кюкяй 1, Кюкяй 2 и Сергелях. Первые два из них датируются XIV - серединой XV в. (Петров, 2019), третье серединой XV - началом XVI в. (Бравина и др., 2016). По определению исследователей в захоронениях Кюкяй 1 и Сергиляхм(рис. 1 - 4) находились пальмы батас, а в погребении Кюкяй 2 пальма батыйа (рис. 1 - 3). Батыйа - охотничья пальма с ножевидным клинком, батас боевая пальма. Отличительными признаками последней являлось наличие на клинке граней жесткости и профиль лезвия в виде ломанной линии из-за двух угловатых выступов ближе к середине и у острия (для усиления пробивного воздействия) (Васильев, 1995, с. 91; Петров, 2019, с. 75). Пальма в захоронении Кюкай 1 располагалась с внутренней стороны правой руки, параллельно туловищу, острием в сторону ног; в захоронении; в Кюкай 2 - снаружи левой ноги, параллельно ей, острие направлено в сторону ступней; в Сергиляхском - снаружи правой ноги, параллельно ей, острием к ступням. Если предположить, что пальма помещалась в могилу с целым древком, то по ее положению в погребальной конструкции можно определить длину его древка. В захоронении Кюкяй 1 она была не более 40 см, в двух других погребениях она могла быть больше.

В захоронениях Якутии раннего периода (XV-XVII вв.), когда пальма помещалась снаружи гроба (Балыктаах, Джусулен, Улахан Алаас и Таралай), она оставалась как правило целой. Исключение составляет захоронение Нэлэгэр, где пальма была намерено сломана. Якуты считали, что такие предметы имели собственную власть и могли исполнить свое предназначение. Поэтому их следовало «убить», а также не позволить душе умершего, превратившейся в юер, воспользоваться ими. В якутских захоронениях XVIII в. пальма была найдена внутри гроба-ящика, рядом с луком (Шаманское Дерево 1, Мунур Урях 1, Юрюнг Мыран 1). В Кус Чарбыт, Орджогон 1 и 2 и в Булгунях 1 пальма находилась снаружи гроба и не была намеренно сломана. Только в Селисе пальма была намеренно сломана и помещена внутри гроба (Мир древних якутов, 2012, c. $98-100)$.

Наиболее ранние черешковые наконечники пальмы обнаружены в южной части Ангарской долины в захоронениях устьталькинской культуры (XII-XIV вв.). Они найдены в трех захоронениях: погребениях № 1 и № 3 могильника Усть-Талькин и погребения № 10 могильника Усть-Уда (Николаев, 2004, с. 89-90). Лучше всего сохранилась пальма из могильника Усть-Уды. Она находилась в колоде, между правой ногой и стенкой колоды и ориентирована острием в сторону головы. Общая длина изделия 137 см (рис. 1 5). Древко круглое в сечении, диаметром 3-3,5 см и длиной около 110 см. Клинок прямой, однолезвийный, узкий, черешок частично обломан. Длина клинка - 27 см, ширина - 2 см, длина сохранившегося черешка $-2,5$ см 
(Николаев, 2004, рис. 99 - 3; рис. 100 - 10). По костям погребенного из могилы № 10 получена радиоуглеродная дата (Николаев, 2004, табл.20), соответствующая с учётом калибровки $(95,4 \%)$ временному интервалу 1276 1401 гг.

Пальмы с насадом в виде несомкнутой втулки

Пальмы с несомкнутой втулкой в настоящее время зафиксирован в четырех регионах - Туве, Прихубсугулье (Монголия), Предбайкалье и Юго-Восточном Забайкалье. Не исключено, что они могут быть найдены и в других частях Северной или Центральной Азии. Так, например, рисунок предмета, напоминающего наконечник пальмы, приводится среди находок из курганов с трупосожжением конца I тыс. н.э. на р. Уень - левого притока Оби, расположенного на границе Томской и Новосибирской областей (Троицкая, 1977, рис. 3 - 14). Какие-либо пояснения относительно места обнаружения этого предмета ни в статье, ни на рисунке не приводятся, поэтому сложно понять его соотношение с раскопанными захоронениями.

К настоящему времени все обнаруженные пальмы с несомкнутой втулкой по сечению клинка относятся к одной группе трехгранных и представлены одним типом - удлиненно-треугольные (Худяков, (1991, с. 18; 1992; Харинский, 2001, с. 141).

Один из наконечников пальмы с несомкнутой втулкой (рис. 1 - 6). А.Д. Грач обнаружил в кургане № 4 могильника Эйлиг-Хем III на территории Тувы в 1965 г. (Кызласов, 1983, табл XVIII - 9). Памятник отнесен И.Л. Кызласовым к эйлигхемскому периоду (конец X - начало XI в) малиновского этапа аскизской культуры (Кызласов, 1983, с. 71) Другой подобный наконечник находится в коллекции Минусинского музея с номером ММ-8380 (Кызласов, 1983, табл XVIII - 8). Характеризуя пальмы с несомкнутой втулкой, И.Л. Кызласов пишет: «Совершенно такие же штыковые ножи встречены в древнехакасских курганах IX-X вв. (Грач, 1971, с. 13, рис. 118). Это редкая находка в погребениях (в тюхтякское время они встречены в поминальных курганах), но подобных изделий много среди случайных находок (мне известно 15 экз.) На боевое назначение таких ножей указывают типологически близкие почти полуметровые экземпляры неизвестного времени, хранящиеся в минусинском музее (МПМ-ш 10а, п.3, к. 22, без №) (Кызласов, 1983, с. 38).
В 1916 г. А.В. Адриановым во время раскопок в Туве кургана № 24 могильника Пий-Хем, почти у северо-западного края кургана, «под слоем камней и на камнях» и «на уров[не] с поверхностью окружающей земли» (видимо, на уровне современной дневной поверхности) обнаружено скопление из 9 предметов, которые исследователь датировал XVIII-XIX вв. В их число входила железная горбуша, железное большое долото, два железных малых долота, железный нож с загнутым остриём, железный топор, железный топор-тесло, фрагмент железной «чаши-сковороды», мелкие фрагменты железного предмета и - каменный брусок. Изделие, обозначенное как железное большое долото (МАЭС ТГУ: колл. 6041), судя по фотографии, является пальмой с несомкнутой втулкой. К сожалению, в публикации отсутствуют поперечные разрезы его клинка и поэтому однозначно говорить о его функциональном использовании сложно (Беликова, 2014, рис. 141 - 2, рис. 143). Л.Р. Кызласов опубликовал краткое описание материалов из кургана 24 («могильник Танам») и датировал его уйгурским периодом - VIII-IX вв. (Кызласов, 1979, с. 193-194). Позже он отнес вещи, обнаруженный у кургана, к IX-X вв. (Кызласов, 1983, 158) По мнению О.Б. Беликовой, скопление найденных вещей датируется XVIII-XIX вв. (Беликова, 2014, с. 196).

На территории Юго-Восточного Забайкалья пальма с несомкнутой втулкой обнаружена в погребении № 2 могильника Чиндант 1, на левом берегу р. Онон. Из 22 погребений, раскопанных на могильнике Чиндант 1, только три захоронения не были потревожены (№ 2. 4, 11). Могильник разновременный. Ко II тыс. н.э. исследователями отнесены захоронения № 1, 2, 4, 6-11, 14, 16, 17, 22 (Асеев и др., 1984, с. 49-56). Учитывая особенности погребального ритуала и сопроводительный инвентарь, обнаруженный в могиле, захоронение № 2 можно датировать XI-XII вв. Погребения № 4, 6-11, 14 датируются XIII-XIV вв. Остальные захоронения сильно разрушены, и поэтому их возраст установить проблематично (Харинский, 2013; 2018; Крадин и др., 2016).

Наконечник пальмы из Чинданта 1 имеет длину 27 см (рис. 2 - 1). Насад выполнен в виде незамкнутой втулки длиной 16,4 см, шириной 2 см и толщиной 0,9 см. Ширина несомкнутого пространства составляет 1,1-1,4 см. Клинок цельнокованный с втулкой. Длина клинка 10,6 см, ширина у основания - 1,2 см. Клинок однолезвийный, с прямым обушком. 
Наконечник пальмы располагался у левого бедра погребенного, рядом с берестяным колчаном (Асеев и др., 1984, рис. 11, с. 52).

На территории Предбайкалья находки наконечников пальм с несомкнутой втулкой фиксируются на островах в верховьях p. Ангары и в Приольхонье (западное побережье Байкала). По данным Ю.С. Худякова, на Ангарских островах обнаружено пять наконечников пальм (Худяков, 1992, с. 111). И.В. Асеев в работе «Прибайкалье в средние века (по археологическим данным)» приводит рисунок, на котором представлены три наконечника пальм и наконечник копья с насадами в виде несомкнутых втулок (Асеев, 1980, табл. XXV). В подписи под рисунком сообщается: «Железные ножи с втульчатой рукояткой». О месте их находки ничего не сообщается. Давая характеристику предметам вооружения, найденных на поселениях с Ангарский островов, И.В. Асеев выделяет четыре группы ножей, в которые включены и изделия с таблицы XXV. К группе 3 он относит: «однолезвийные с втульчатой рукояткой (см. табл. XXV, 1, 3, 4)». В группу 4 им включены: «обоюдоострые с клинком листовидной формы, которые делятся также на два вида: а) черешковые (см. табл. XXIV, 1, 2), б) втульчатые с отверстием для крепления (см. табл. XXV, 1, 2)» (Асеев, 1980, с. 99). При этом «нож», изображенный в таблице XXV под № 1, отнесен исследователем одновременно к однолезвийным и обоюдоострым. Скорее всего, И.В. Асеев описался, потому что ниже, характеризуя однолезвийные ножи с втульчатой рукояткой, он упоминает 3 экземпляра, а среди обоюдоострых ножей с коротким втульчатым черешком один экземпляр. Указывая местонахождение «однолезвийных ножей», он пишет: «Ножей с втульчатой рукояткой на о-ве Лесном найдено три» (Асеев, 1980, с. 99). Но этой информации противоречат данные, приводимые И.В. Асеевым выше. Перечисляя находки с Ангарских островов, исследователь упоминает о том, что два «ножа с втульчатой рукояткой» (табл. XXV - 3, 4), обнаружены во время раскопок на левом берегу острова Сосновый, на участке 7 (Асеев, 1980, с. 87). В связи с этим возникает вопрос, где же всё-таки были найдены эти изделия на острове Сосновом или острове Лесном?

Наконечник пальмы неизвестного происхождения (Асеев, 1980, табл. XXV, 1), скорее всего был обнаружен на одном из островов в истоке Ангары. Его параметры, как и двух других приводятся по рисункам из работы И.В. Асеева (табл. XXV - 1, 3, 4). У него обломано острие. Длина сохранившейся части 22 см (рис. 2 - 2). Насад выполнен в виде незамкнутой втулки длиной $12,3 \mathrm{~cm}$, шириной $2 \mathrm{~cm}$ и толщиной 1,4 см. У края втулки, в ее центре имеется круглое отверстие для крепления к древку. Ширина несомкнутого пространства составляет 1,0-1,2 см. Клинок цельнокованный с втулкой. Длина сохранившейся части клинка 9,7 см, ширина у основания - 1,7 см. Клинок однолезвийный, с прямым обушком.

Один из наконечников пальмы, вероятно, обнаруженный на Сосновом острове, имеет длину 13 см (рис. 2 - 3). Насад выполнен в виде незамкнутой втулки длиной 7,5 cм, шириной 1,7 см и толщиной 1 см. На конце втулка расширяется до 1,9 см. У края втулки, в ее центре имеется круглое отверстие для крепления к древку. Ширина несомкнутого пространства составляет 0,9-1,0 см. Клинок цельнокованный с втулкой. Длина клинка 5,5 см, ширина у основания - 1,5 см. Клинок однолезвийный, с прямым обушком.

Второй из наконечников пальмы с Соснового острова имеет длину 13 см (рис. 2 - 4). Насад выполнен в виде незамкнутой втулки длиной 6,8 см, шириной 1,9 см и толщиной 1 см. У края втулки, в ее центре имелось круглое отверстие для крепления к древку. В дальнейшем край втулки до отверстия обломился. Ширина несомкнутого пространства составляет 1,0-1,3 см. Клинок цельнокованный с втулкой. Длина клинка 6,2 см, ширина у основания - 1,6 см.

На территории Приольхонья обнаружено два наконечника пальмы (Харинский, 2001, c.141). Один из них найден в захоронении Куркут 2 - 1 (Харинский, 2001, рис.41 - 2). Насад наконечника выполнен в виде незамкнутой втулки длиной 9,5 cм, шириной $1,9 \mathrm{~cm}$ и толщиной 1 см (рис. 2 - 5). Ширина несомкнутого пространства составляет 0,8-1,0 см. Основание клинка с внутренней стороны приварено к втулке. Длина клинка 6,5 см, ширина у основания - 1 см. Клинок однолезвийный, с прямым обушком. На клинок надевались деревянные ножны длиной 12,5 cм, остатки от которых фиксируются на пальме. Наконечник пальмы располагался с внутренней стороны правой плечевой кости. Он был обращен острием к югу, сам же погребенный ориентирован головой на северо-восток. Если предположить, что в погребении пальма сохранила свое первоначальное положение и 
не была сломана перед помещением в могилу, то можно определить примерную длину ее древка, которая составляла не более $20 \mathrm{~cm}$. Если бы оно было длинней, то не поместилось в яму, в том положении, которое зафиксировано во время раскопок (Харинский, 2001, рис. 40).

Вторая пальма найдена в захоронении Хужиртуй 3 - 1 (Харинский, 2001, рис.52-1). Она цельнокованная с незамкнутым втульчатым насадом. Длина втулки 10 см, ширина у конца - 2,1 см и толщина - 1 см (рис. 2 -6). Ширина несомкнутого пространства составляет 0,3-1,3 см. Длина клинка 9 см, ширина у основания - 1 см. Клинок однолезвийный, с прямым обушком. Во внутренней части втулки располагаются два шпенька, с помощью которых пальма крепилась к древку. Шляпки шпеньков имеют диаметр 0,7 см. Наконечник пальмы располагался между ног погребенного, ориентированного головой на восток. Ее острие направлено на юго-запад, к нижнему эпифизу левой берцовой кости. Если положения наконечника в могиле не изменилось с момента захоронения, и древко не было сломано, то его длина составляла не более 70 см (Харинский, 2001, рис. 51).

На северном побережье Хубсугула (Северная Монголия) наконечники пальмы с несомкнутой втулкой обнаружены на двух могильниках Хавцал 2 и Зуун хярын дэнж 1. На могильнике Хавцал 2 пальма найдена в погребении, впущенном в курганную насыпь херексура, предварительно датирующегося второй половиной II - первой половиной I тыс. до н.э. (Харинский и др., 2010). Длина клинка 8 см. Обушок слегка вогнутый, толщиной 3 мм, к острию он становится тоньше (рис. 2 - 7). Ширина лезвия в основании 1,2 см. Клинок заточен только с правой стороны. К острию лезвие загибается вверх. Клинок отделяется от насада слегка обозначенным лезвийным уступом Втулка конусовидная длиной 8,5 см, ширина в основании $1,1 \mathrm{~cm}$, ширина окончания 2 см. в сечении втулка овальной формы, толщина стенок 3 мм. Втулка не замкнута. С правой стороны имеется незамкнутое пространство. У основания втулки расстояние между незамкнутыми краями втулки 0,8 см, у окончания - 1,3 cм. У конца край втулки отогнут наружу, образуя уступ толщиной 4 мм. длина пальмы 17.6 см.

На могильнике Зуун хярын дэнж 1 цельнокованый клинок пальмы обнаружена под камнями кладки комплекса № 1 (Оргилбаяр и др., 2019). Ее длиной 207 мм (рис. 2 - 8). Длина клинка 112 мм, длина втулки 95 мм. Клинок с прямым обушком, сужающийся со стороны лезвия. Ширина основания клинка 14 мм. Толщина обушка от 5 мм у основания до 1 мм у острия. Заточка клинка односторонняя. Со стороны несомкнутой части втулки сторона клинка прямая, с противоположной стороны у клинка имеется скос к лезвию. Основание втулки стыкуется с клинком, шириной 14 мм. Ширина конца втулки 25 мм. Втулка трапециевидной формы, сужается к основанию. Ее толщина 6 мм. Толщина стенок втулки около 2 мм. Края стенок втулки располагаются перпендикулярно ее боковым стенкам. Они не загибаются внутрь.

Судя по опубликованным к настоящему времени материалам на территории Байкальского региона, включающего три субъекта Российской Федерации Иркутскую область, Республику Бурятия, Забайкальский край и север Монголии с бассейном р. Селенги, обнаружено 8 наконечников пальм с несомкнутой втулкой. Три из них найдены на поселении и пять в захоронениях (рис. 3). Три наконечника пальм располагались в могильной яме вместе с останками погребенного, один среди камней кладки захоронения, и один в разрушенном грабителями впускном погребении.

\section{Обсуждение}

Для определения времени использования на территории Байкальского региона пальм с наконечниками, имеющими насад в виде несомкнутой втулки, обратимся, прежде всего, к погребениям по которым имеются радиоуглеродные даты. К их числу относятся захоронения могильников Хужиртуй 3, Хавцал 2, Зуун хярын дэнж 1 (табл. 1).

Судя по радиоуглеродным данным, самым ранняя пальма фиксируется во впускном захоронении комплекса № 1 могильника Хавцал 2 , возраст которого соотносится с концом VIII - первой половиной XI вв. Погребение № 1 могильника Хужиртуй 3 датируется концом IX - первой половиной XI вв. Возраст захоронения № 1 могильника Зуун хярын дэнж 1 соответствует первой половине XI - середине XII вв. Таким образом время использования пальм с несомкнутой втулкой в Байкальском регионе предварительно может быть определено концом VIII - серединой XII вв. Материалы с других памятников, на которых были обнаружены такие наконечники, не противоречат этим данным. В XIII-XIV вв. пальмы с несомкнутой втулкой уже не встречаются на 
Таблииа 1.

Радиоуглеродные даты по захоронениям, в которых обнаружены пальмы с насадом в виде несомкнутой втулки

Table 1.

Radiocarbon dates for burials with discovered palmas with tips in the form of open sleeves

\begin{tabular}{|c|c|c|c|c|c|c|}
\hline Объект & № могилы & Материал & Лаб. № & ${ }^{14}$ С & $+/-$ & $\begin{array}{c}\text { Калибров. возраст } \\
(\text { н.э.) })^{*}\end{array}$ \\
\hline Хужиртуй 3 & могила № 1 & кости человека & $\begin{array}{c}\text { СОАН- } \\
3704\end{array}$ & 1080 & 40 & $886-1029$ \\
\hline Хавцал 2 & $\begin{array}{c}\text { впускное погребение } \\
\text { в комплекс № 1 }\end{array}$ & кости человека & $\begin{array}{c}\text { СОАН- } \\
7572\end{array}$ & 1090 & 50 & $774-1033$ \\
\hline $\begin{array}{c}\text { Зуун хярын } \\
\text { дэнж 1 }\end{array}$ & могила № 1 & зуб человека & $\begin{array}{c}\text { ОхА- } \\
39271\end{array}$ & 930 & 17 & $1038-1156$ \\
\hline
\end{tabular}

Даты и их промежутки погрешностей калиброваны в программе Oxcal 4.3 (Bronk Ramsey, 2017) при помощи базы данных IntCal13 (IntCal13 ..., 2013), доверительный интервал калиброванной датировки 95,4\%

территории Байкальского региона (Крадин и др., 2016; Харинский, 2018). На просторах Евразии получает распространение оружейный комплекс, в основу которого составляло вооружение монголов, создавших огромную империю.

Наконечники пальм с несомкнутой втулкой обнаружены в захоронениях со схожим погребальным ритуалом. Могилы располагались на вершинах холмов или на склонах гор. Захоронения совершались в грунтовых ямах. Умершего укладывали вытянуто, на спину на грунт или деревянную доску, иногда помещали в берестяной чехол. Сверху его могли накрывать деревянной крышкой. Покойников ориентировали головой на север, северо-восток или восток. Над могильной ямой сооружалась круглая кладка диаметром 3-4 м. Близость погребального ритуала и инвентаря, фиксируемого в прихубсугульских и прибайкальских захоронениях не удивительна. Они принадлежали родственным народам - туматам, хори и баргутам, являвшимся потомками трех тюркоязычных телесских народов - дубо, гулигань и байырку. Общность их происхождения, вероятно, способствовала формированию схожих представлений о погребальном обряде и использовании близкого набора инвентаря. К середине XIII в. область расселения этих народов меняется, что находит отражение в изменениях, происходивших в погребальной практике, как в Прибайкалье, так и в Прихубсугулье.

Миграции населения, ставшие следствием монгольских завоеваний, затронули и потомков телесского населения Байкальского региона. Скрываясь от монголов, часть гули- гань-хори, а возможно и дубо-туматов, продвинулась вниз по долине р. Лена, став одной из составляющих якутского народа. Когда произошло это переселение к настоящему времени достаточно уверенно сказать сложно. Но одним из его свидетельств может служить находка на поселении Кытанах Маллата в междуречье Лены и Амги в Центральной Якутии наконечника пальмы с несомкнутой втулкой (рис. 2 - 9) (Гоголев, 1990, табл. IX 5). А.И. Гоголев относит находки с этого поселения к кулан-атахскому этапу кулан-атахской культуры и датирует XIV-XV вв. (Гоголев, 1990, c. 23).

\section{Заключение}

Пальма как один из видов древкового оружия в первые века своего существования не получила широкого распространения. Ее находки фиксируются на территории, протянувшейся от верховьев Енисея на западе, до верховьев Онона на востоке. К настоящему времени самый ранний ее образец обнаружен на северном берегу озера Хубсугул на могильнике Хавцал 2. На основании радиоуглеродного анализа, захоронение, в котором найдена пальма, датируется концом VIII - первой половиной XI вв. Наконечник пальмы крепился к древку с помощью несомкнутой втулки. B IX-X вв. этот вид оружия распространяется в остепненных районах Предбайкалья, Забайкалья и Тувы, где проживали потомки тюркоязычных племен теле. В оружейном наборе этих регионов она не занимает ведущее положение, уступая место оружию дистанционного боя - луку со стрелами. С XIII пальмы с несомкнутой втулкой уже не встречается среди вооружения скотоводов кочевников 
и полукочевников Байкальского региона и Тувы. При этом она не исчезает полностью на территории Восточной Сибири, а проникает в её более северные районы. В результате миграции части предбайкальского населения в первой половине II тыс. н.э. в среднюю часть долины Лены, пальма с несомкнутой втулки появляется в Ленско-Амгинском междуречье.

Пальма с втульчатым насадом становится основой для формирования пальм с черешковым насадом. Самые ранние их образцы найдены в южной части Ангарской долины в захоронении могильника Усть-Уда, дати- рующемся концом XIII-XIV вв. и относящемся к Усть-Талькинской культуре. Вместе с усть-талькинцами этот вид вооружения в XIV в. проникает в среднюю часть долины Лены и в долину Вилюя, становясь прототипом для двух разновидностей черешковых пальм - батас и батыйа. C XVII в. пальма c черешковым насадом получает широкое распространяется среди жителей лесной зоны Северной Азии, становясь одним из важнейших видов вооружения у якутов, эвенков, селькупов, хантов, кетов и других сибирских и дальневосточных народов.

\section{ЛИТЕРАТУРА}

Асеев И.В. Прибайкалье в средние века. Новосибирск: Наука, 1980. 149 с.

Асеев И.В., Кириллов И.И., Ковычев Е.В. Кочевники Забайкалья в эпоху средневековья. Новосибирск: Наука, 1984. 201 с.

Беликова О.Б. Последняя экспедиция А.В. Адрианова: Тува, 1915-1916 гг. Археологические исследования (источниковедческий аспект) / отв. ред. Д.Г. Савинов. Томск: Изд-во Том. ун-та, 2014. 570 с.

Бравина Р.И., Дьяконов В.М., Николаев Е.Н., Петров Д.М., Сыроватский В.В., Багашев А.Н., Пошехонова О.Е., Слепченко С.М., Ражев Д.И., Алексеева Е.А., Зубова А.В., Кузьмин Я.В. Комплексное исследование раннеякутского сергеляхского погребения середины XV - начала XVI в. // Вестник археологии, антропологии и этнографии. 2016. № 4 (35). С. 90-109.

Василевич Г.М. Эвенки. Историко-этнографический очерк. Л.: Наука, 1969. 304 с.

Васильев Ф.Ф. Военное дело якутов. Якутск: Бичик, 1995. 224 с.

Гоголев А.И. Археологические памятники Якутии позднего средневековья (XIV-XVIII вв.). Иркутск: Изд-во Иркут. ун-та, 1990.189 с. 3160

Грач А.Д. Отчет о полевых исследованиях 1-го отряда СТЭАН в 1965 г. // Архив ИА АН СССР. д. 4614.

Грач А.Д. Отчет о полевых исследованиях 1-го отряда СТЭАН в 1971 г.- Архив ИА АН СССР. д.

Крадин. Н.Н., Харинский А.В., Бакшеева С.Е., Ковычев Е.В., Прокопеи С.Д. Археология империи Чингис-хана в Монголии и Забайкалье // Stratum plus. 2016. № 6. С. 17-43.

Кызласов И.Л. Аскизская культура Южной Сибири X-XIV вв. / САИ. Вып. Е3-18. М.: Наука, 1983. $128 \mathrm{c}$.

Кызласов Л.Р. Древняя Тува (от палеолита до ІХ в.). М.: Изд-во МГУ, 1979. 208 с.

Кызласов Л.Р. Курганы тюхтятской культуры в Туве (по материалам раскопок 1915-1929 гг.) // СА. 1983. № 3. С. 153-170.

Мир древних якутов: опыт междисциплинарных исследований (по материалам Саха-французской археологической экспедиции) / Под ред. Э. Крюбези и А.Н. Алексеева. Якутск: Издательский дом СВФУ, 2012. 226 c.

Оргилбаяр С., Харинский А.В., Эрдэнэбаатар Д., Мандалсүрэн Н. Монгол-Оросын хамтарсан “Төв Азийн археологийн шинжилгээ-1" төслийн Хөвсгөл аймгийн Ханх сумын нутагт явуулсан малтлага судалгааны ажлын урьдчилсан үр дүнгээс // Монголын археологи - 2018 / Ер. Ред. Д.Эрдэнэбаатар Улаанбаатар хот, 2019. С. 140-146.

Пекарский Э.К. Словарь якутского языка. М.: Изд-во АН СССР, 1958. Т. 1. 1280 с.

Петров Д.М. Захоронение воинов на озере Кюкяй в Западной Якутии: новые материалы по ранней этнической истории вилюйских якутов (XIV-XV вв.) // Известия Лаборатории древних технологий. 2019. № 2(15). С. 67-80.

Серошевский В.Л. Якуты. Опыт этнографического исследования. М., 1993. 736 с.

Троицкая T.Н. Погребения с трупоссожениями конца I тысячелетия н.э. на р. Уени Новосибирской области // Археология Южной Сибири. Вып. 9./ Отв. ред. А.И. Мартынов. Кемерово: Изд-во Кемеровского гос. ун-та, 1977. С. 121-130. 
Харинский А.В. Оружие эвенков северного побережья озера Байкал в XVIII-XIX вв. // Известия Лаборатории древних технологий. / Отв. ред. А.В. Харинский. Иркутск: Изд-во ИрГТУ, 2003. Вып. 1. C. $113-122$.

Харинский А.В. Погребальная практика монголов в XIII-XIV вв. // Древние культуры Монголии и Байкальской Сибири: материалы IV междунар. науч. конф. Ч. II / Отв. ред. А.В. Константинов, М.В. Константинов. Чита: Изд-во Забайкал. гос. ун-та, 2013. С. 125-131.

Харинский А.В. Приольхонье в средние века: погребальные комплексы. Иркутск: Изд-во ИрГТУ, 2001. $238 \mathrm{c}$.

Харинский А.В. Южное Прибайкалье накануне образования монгольской империи // Археология Евразийских степей. 2018. № 4. С. 187-192.

Харинский А.В., Эрдэнэбаатар Д., Коростелев А.М. Херексур - универсальный объект погребальной практики // Культура как система в историческом контексте: опыт западно-сибирских археологоэтнографических совещаний / Отв. ред. М.П. Черная. Томск: Изд-во Аграф-Пресс, 2010. С. 322-324.

Худяков Ю.С. Вооружение центральноазиатских кочевников в эпоху раннего и развитого средневековья. Новосибирск: Наука, 1991. 190 с.

Худяков Ю.С. Наконечники копий и «пальм» из средневековых памятников Прибайкалья, Забайкалья и Монголии // Археологические памятники эпохи средневековья в Бурятии и Монголии / Отв. ред. П. Б. Коновалов Новосибирск: Наука, 1992. С. 107-117.

Худяков Ю.С. Наконечники копий из памятников IX-XII вв. в Туве // Новейшие исследования по археологии Тувы и этногенез тувинцев / Отв. ред. А.П. Окладников. Кызыл: Изд-во Тувинского научноисследовательского института языка, литературы и истории, 1980. С. 95-101. 1833

Bronk Ramsey C. Methods for Summarizing Radiocarbon Datasets // Radiocarbon. 59(2). 2017. 1809-

Reimer, P. J., Bard,E., Bayliss, A., Beck, J.W., Blackwell, P. G., Bronk Ramsey, C., Grootes, P. M., Guilderson, T. P., Haflidason, H., Hajdas, I., Hatte, C. Heaton, T. J. Hoff-mann, D. L., Hogg, A. G., Hughen, K. A., Kaiser, K. F., Kromer, B., Manning, S. W., Niu, M. R., Reimer, W., Richards, D. A., Scott, E. M., Southon, J. R., Staff, R. A., Turney,C. S. M., van der Plicht, J. IntCal13 and Marine13 Radiocarbon Age Calibration Curves 0-50,000 Years cal BP // Radiocarbon. 2013. Vol. 55 (4). P. 1869-1887.

\section{Информация об авторе:}

Харинский Артур Викторович, доктор исторических наук, профессор (г. Иркутск, Россия).

\section{REFERNCES}

Aseev, I. V. 1980. Pribaikal'e v srednie veka (Baikal Region in the Middle Ages). Novosibirsk: "Nauka" Publ. (in Russian).

Aseev, I. V., Kirillov, I. I., Kovychev, E. V. 1984. Kochevniki Zabaikal'ia v sr'dnevekov'ia (Nomads of Transbaikalia in the Middle Ages). Novosibirsk: "Nauka" Publ. (in Russian).

Belikova, O. B. 2014. Posledniaia ekspedisiia A.V. Adrianova: Tuva, 1915-1916 gg. Arkheologicheskie issledovaniia (istochnikovyi aspect) (The Last Expedition of A.V. Adrianov: Tuva, 1915-1916. Archaeological Studies (Source Study Aspect)). Tomsk: Tomsk State University (in Russian).

Bravina, R. I., D’yakonov, V. M., Nikolaev, E. N., Petrov, D. M., Syrovatsky, V. V., Bagashev, A. N., Poshekhonova, O. E., Slepchenko, S. M., Razhev, D. I., Alekseeva, E. A., Zubova, A. V., Kuzmin, Ya. V. 2016. In Vestnik arkheologii, antropologii i etnografii (Bulletin of Archaeology, Anthropology and Ethnography) 35 (4), 90-109 (in Russian).

Vasilevich, G. M. 1969. Evenki. Istoriko-etnograficheskii ocherk (The Evenks. Historical and Ethnographic Essay). Leningrad: "Nauka" Publ. (in Russian).

Vasil'ev, F. F. 1995. Voennoe delo yakutov (Military Art of the Yakuts). Yakytsk: "Bichik" (in Russian).

Gogolev, A. I. 1990. Arkheologicheskie pamiatniki Yakutii pozdnego srednevekov'ia (XIV - XVIII vv.) (Archaeological Monuments of Yakutia of the Late Middle Ages (14th-18th cc.)). Irkutsk: Irkutsk State University (in Russian).

Grach, A. D. 1965. Otchet o polevykh issledovaniiakh pervogo otriada Saiano-Tuvinskoi ekspeditsii Akademii nauk SSSR v 1965 g. (Report on Field Studies of the 1st Group of the Sayano-Tuva Archaeological Expedition of the Academy of Sciences in 1965). Archive of the Institute of Archaeology, Academy of Sciences of the USSR. Dossier 3160 (in Russian). 
Grach, A. D. 1971. Otchet o polevykh issledovaniiakh pervogo otriada Saiano-Tuvinskoi ekspeditsii Akademii nauk SSSR v 1971 g. (Report on Field Studies of the 1st Group of the Sayano-Tuva Archaeological Expedition of the Academy of Sciences in 1971). Archive of the Institute of Archaeology, Academy of Sciences of the USSR. Dossier 4614 (in Russian).

Kradin, N. N., Kharinsky, A. V., Bakshieva, S. E., Kovychev, E. V., Prokopets, S. D. 2016. In Stratum plus. Archaeology and Cultural Anthropology (6), 17-43 (in Russian).

Kyzlasov, I. L. 1983. Askizskaya kul'tura Yuzhnoy Sibiri X-XIVvv. (Askizskaya Culture of South Siberia in the 10th-14th cc.). Series: Svod Arkheologicheskikh Istochnikov (Corpus of Archaeological Sources) E3-18. Moscow: "Nauka" Publ. (in Russian).

Kyzlasov, I. L. 1979. Drevniaia Tuva (ot paleolita do IXv.) (Ancient Tuva (from the Paleolithic to the 9th c.). Moscow: Moscow State University (in Russian).

Kyzlasov, L. R. 1983. In Sovetskaia Arkheologiia (Soviet Archaeology) (3), 153-170 (in Russian).

Kryubezi, E., Alekseev, A. N. (eds.). 2012. Mir drevnikh yakutov: opyt mezhdisrsiplinarnykh issledovanii (po materialam Sakha-frantsuzskoi arkheologicheskoi ekspeditsii (The World of Ancient Yakuts: the Experience of Interdisciplinary Studies (Based on the Materials of the Sakha-France Archaeological Expedition). Yakutsk: North-Eastern Federal University (in Russian).

Orgilbayar, S., Kharinsky, A. V., Erdenebaatar, D., Mandalcyuren, N. 2019. In Erdenebaatar, D. (ed.). Mongolyn arkheologi (Mongolian archaeology - 2018). Ulaanbaatar, 140-146 (in Mongolian).

Pekarsky, E. K. 1958. Slovar' iakutskogo iazyka (Словарь якутского языка.). Moscow: Academy of Sciences of the USSR (in Russian).

Petrova, D. M. 2019. In Izvestiya Laboratorii drevnikh tekhnologiy (Review of the Laboratory of ancient technologies) 15(2), 67-80 (in Russian).

Seroshevsky, V. L. 1993. Yakuty. Opyt etnograficheskogo issledovaniia (Yakuts. The Experience of Ethnographic Studies). Moscow: "Rossiiskaia politicheskaia entsiklopediia" Publ. (in Russian).

Troitskaya, T. N. 1977. In Martynov, A. I.. (ed.). Arkheologiia Iuzhnoi Sibiri (Archaeology of South Siberia) 9. Kemerovo: Kemerovo State University Publ., 121-130 (in Russian).

Kharinsky, A. V. 2001. Priol'khonie v srednie veka: pogrebal'nye kopleksy (The Olkhon River Region in the Middle Ages: Burial Complexes). Irkutsk: Irkutsk State Technical University (in Russian).

Kharinskiy, A. V. 2003. In Kharinskiy, A. V. (ed.). Izvestiya Laboratorii drevnikh tekhnologiy: sbornik nauchnykh trudov (Review of the Laboratory of ancient technologies: a collection of scientific papers) 1. Irkutsk: Irkutsk State Technological University Publ., 113-122 (in Russian).

Kharinskiy, A. V. 2013. In (ed.). In Konstantinov, A. V., Konstantinov, M. V. (eds.). Drevnie kul'tury Mongolii i Baykal'skoy Sibiri (Ancient Cultures of Mongolia and Baikal Siberia) 4 (2). Chita: Chita State University Publ., 125-131 (in Russian).

Kharinsky, A. V. 2018. In Arkheologiia Evraziiskikh stepei (Archaeology of Eurasian Steppes) 4, 187-192(in Russian).

Kharinsky, A. V., Erdenebaatar, D., Korostelev, A. M. 2010. In Chernaya, M. P. (ed.). Kul'tura kak sistema $v$ istoricheskom kontekste: opyt zapadno-sibirskikh arkheologo-etnograficheskikh soveshchanii (Culture as a system in a Historical Context: the Experience of West Siberian Archaeological and Ethnographic Meetings). Tomsk: "Agraf-Press" Publ., 322-324 (in Russian).

Khudyakov, Yu. S. 1991. Vooruzhenie tsentral'noaziatskikh kochevnikov v epokhu rannego i razvitogo srednevekov'ya (Armament of Central Asian Nomads in the Early and Developed Middle Ages). Novosibirsk: "Nauka" Publ. (in Russian).

Khudyakov, Yu. S. 1980. In Okladnikov, A. P. (ed.). Noveishie issledovaniia po arkheologii Tuvyi etnogenez tuvintsev (The Latest Studies on the Archaeology of Tuva and the Ethnogenesis of the Tuvinians). Kyzyl: Tuva Sientific Research Institute of Language, Literature and History, 95-101 (in Russian).

Khudyakov, Yu. S. 1992. In Konovakov, P. B. (ed.). Arkheologicheskie pamiatniki epokhi srednevekov'ia v Buriatii i Mongolii (Archaeological Sites of the Middle Ages in Buryatia and Mongolia). Novosibirsk: "Nauka" Publ., 107-117 (in Russian).

Bronk Ramsey, C. 2017. In Radiocarbon. 59(2), 1809-1833.

Reimer, P. J., Bard,E., Bayliss, A., Beck, J. W., Blackwell, P. G., Bronk Ramsey, C., Grootes, P. M., Guilderson, T. P., Haflidason, H., Hajdas, I., Hatte, C. Heaton, T. J. Hoff-mann, D. L., Hogg, A. G., Hughen, K. A., Kaiser, K. F., Kromer, B., Manning, S. W., Niu, M. R., Reimer, W., Richards, D. A., Scott, E. M., Southon, J. R., Staff, R. A., Turney,C. S. M., van der Plicht, J. 2013. In Radiocarbon. Vol. 55 (4), 1869-1887. 


\section{About the Author:}

Kharinsky, Artur V., Doctor of Historical Sciences (Irkutks, Russian Federation).

Статья поступила в журнал 01.08.2020 г. Статья принята к публикации 01.09.2020 г.
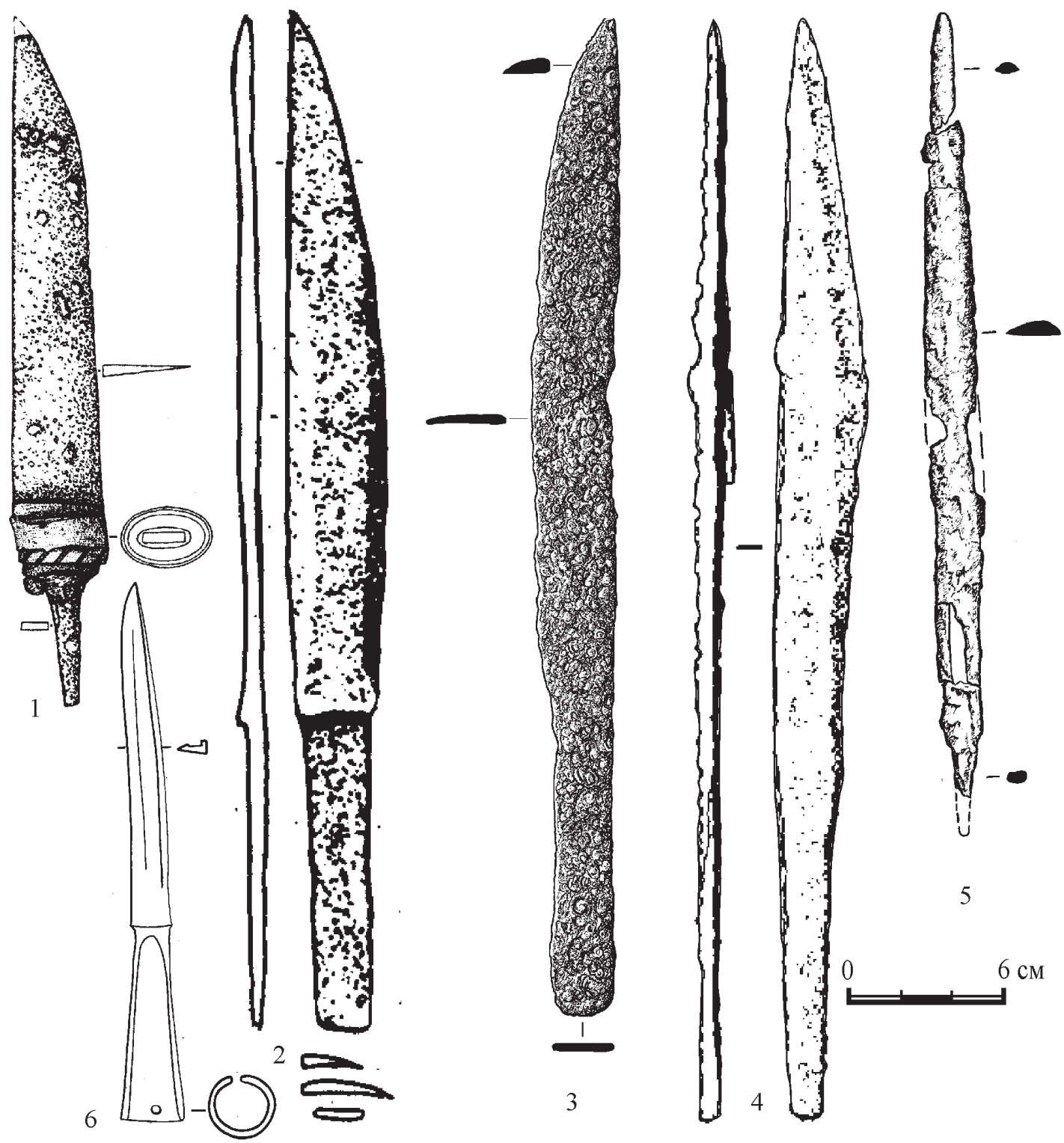

Рис. 1. Пальмы Восточной Сибири: 1 - Лударская губа 1 (Харинский, 2003); 2 - Оргумай, (Гоголев, 1990); 3 - Кюкяй II (Петров, 2019); 4 - Сергилях (Бравина и др., 2016); 5 - Усть-Уда - 10 (Николаев, 2004); 6 - Эйлиг-Хем III - 4 (Кызласов, 1983).

Fig. 1. Palmas of Eastern Siberia: 1 - Ludarskaya guba 1 (Kharinskiy, 2003); 2 - Orgumay, (Gogolev, 1990); 3 - Kyukyay II (Petrov, 2019); 4 - Sergilyakh (Bravina et al., 2016); 5 - Ust'-Uda - 10 (Nikolayev, 2004); 6 - Eylig-Khem III - 4 (Kyzlasov, 1983). 


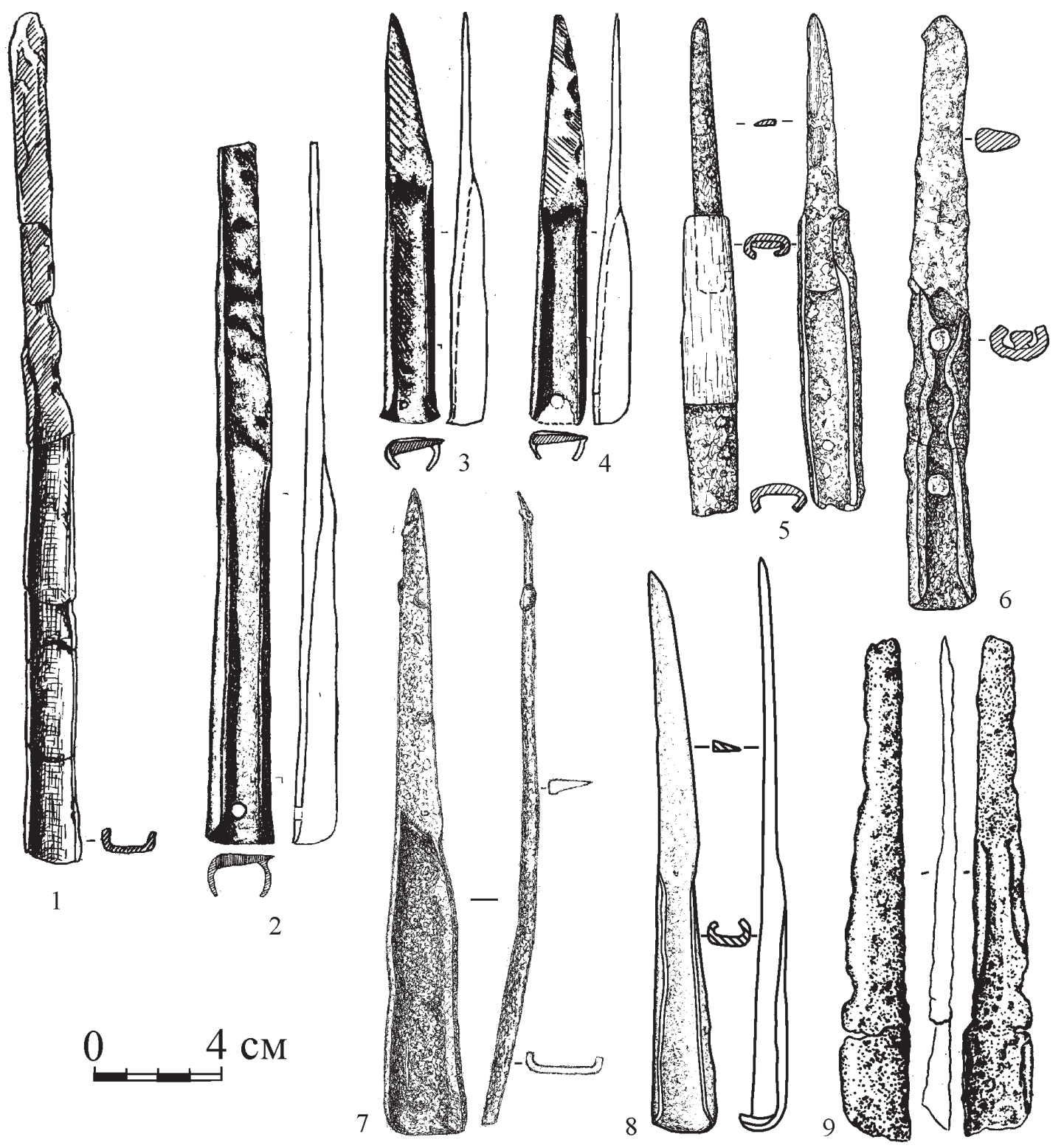

Рис. 2. Пальмы с насадом в виде несомкнутой втулки:

1 - Чиндант 1 - 2 (Асеев и др., 1984); 2-4 - острова в верховьях Ангары (Асеев, 1980); 5 - Куркут 2 - 1 , 6 - Хужиртуй 3 - 1 (Харинский, 2001); 7 - Хавцал 2 - 1 (Харинский и др., 2010); 8- Зуун хярын дэнж 1 - 1 (Оргилбаяр и др, 2019); 9 - Кытанах Маллата (Гоголев, 1990).

Fig. 2. Palmas with a nozzle in the form of an open sleeve:

1 - Chindant 1 - 2 (Aseev et al., 1984); 2-4 - Islands in the upper reaches of the Angara (Aseev, 1980); 5 - Kurkut 2-1, 6 - Khuzhirtuy 3 - 1 (Kharinsky, 2001); 7 - Hawtsal 2 - 1 (Kharinsky et al., 2010); 8 - Zuun khyaryn dange 1 - 1 (Orgilbayar et al, 2019); 9 - Kytanakh Mallata (Gogolev, 1990). 




